\title{
Profile of Skills Students in Resolving Problems Trigonometry Based on Personality Type Myer-Briggs
}

\author{
Dewi Anggreini*, Daffit Krisna Saputra** \\ Mathematics Education STKIP PGRI Tulungagung \\ JL. Mayor Sujadi East, No.17. Plosokandang, Tulungagung, East Java, Indonesia. \\ E-mail: anggreini_004@yahoo.com*, daffitkrisnasaputra@gmail.com**
}

\begin{abstract}
The problem in this study is the low ability of students to solve problems. That is because students only refer to the examples of questions given by the teacher so that students have difficulty if given questions that are not the same as the examples given by the teacher. Diverse problem solving solutions are needed because students still find difficult to draw conclusions from the questions they have worked on. The purpose of this study is to describe students' ability to solve trigonometric problems in terms of the personality type of Myer-Briggs, namely ISTJ, ESFJ, ESTP, INFJ, ISTJ, ISTP, ESTJ, INTP and ISFJ. This research is a type of descriptive research using a qualitative approach. Methods of data collection using the MBTI questionnaire, math problem solving ability test questions and interviews. The results showed that the ISTJ personality type fulfilled 4 indicators of problem solving very well, while the personality types of ESFJ, ESTP, INFJ, ISTJ, ISTP, and ESTJ met 4 indicators of problem solving well, and for personality types ENTJ, INTP, and ISFJ were sufficient good by meeting 3 of the 4 indicators of problem solving. The results of the study can be used to improve students' mathematical problem solving abilities by further enhancing the positive characteristics present in students. Can inspire students to better understand the type of personality they have in themselves and hone their abilities to be more improved.
\end{abstract}

Keywords: Problem Solving Ability, Mathematical, Personality Types.

\section{INTRODUCTION}

Problem-solving ability of students in low into the background in this study. That is because the students simply refers to examples of questions given by the teacher so that students have difficulty if given problems are not the same as the example given by the teacher. Required solutions to problems as diverse as the students are still difficult to make conclusions on the questions that have been done. Learning math has a function as a means to develop critical thinking skills, logical, creative, communication, problem solving, and cooperation are needed for students of modern life. This creative thinking skills related to the ability to identify, analyze (Hasanah, Revelation, \& Sons, 2017), The purpose of this study is to describe the ability of students to solve trigonometry problems in terms of Myer-Briggs personality type ISTJ, ESFJ, ESTP, INFJ, ISTJ, ISTP, ESTJ, INTP, and ISFJ.

Myers and Briggs personality types formulate broadly based on Jung's theory that is used to identify individuals in the decision he shared into four scales of preference based on: (1) The dimensions of focus (introvert-extrovert); (2) The dimensions of obtaining information (sensing-intuition); (3) The dimensions of decision making (thinking-feeling); and (4) The dimensions of observing and assessing (judgingperceiving), (U. Hasanah, 2017).

Rohim and Sari (2019), examine the personality type sensing and intuition, while in this study examined Myer-Briggs personality type. Research Aryanto et al.,
(2018), Use Keirsey personality type while this study using Myer-Briggs personality type with 9 students as research subjects. Razak et al.,(2018), Using a melancholy personality type, where as this study used the Myer-Briggs personality type.

Some experts express their opinions related to understanding the problem. Problem as a question where someone wants the question can be solved, but he did not know immediately how to solve it (N.Hasanah, 2009), According to Dewey in Rina, "A problem is defined broadly as what one does when one does not know what to do". The meaning of the sentence is an issue broadly defined as what one does when one does not know what to do (Agustina, 2014), Troubleshooting Polya classified into two types, namely (1) The problem to find and (2) Problems to Prove, (Yuwono, 2010),

Mathematical problem solving ability is an ability which students attempt to find a way out made in achieving the goal, also requires readiness, creativity, knowledge and skills and their application in everyday life. Mathematical problem solving ability is one of the students need to have the ability, for solving the problem of great benefit to the student to see the relevance of mathematics to other subjects, as well as in real life. Students are said to be able to solve mathematical problems if they can understand, choosing the right strategy, then implement it in problem solving (Aziz, et.al, 2014), Indicators according to the mathematical problem solving (Ilmiyana, 2018) Polya based measures presented in Table 1 following: 
Table 1. Indicators of mathematical problem solving.

\begin{tabular}{|c|c|c|}
\hline Step & Solution to problem & Indicator \\
\hline 1. & $\begin{array}{l}\text { Understanding the problem } \\
\text { (understanding the problem) }\end{array}$ & $\begin{array}{l}\text { a. Students can determine what you know: } \\
\text { b. Students can determine things asked of matter }\end{array}$ \\
\hline 2. & Plan completion (devising a plan) & $\begin{array}{l}\text { a. Students can determine other terms not known at the matter as a formula or } \\
\text { other information if there is one. } \\
\text { b. Students can use all the available information on the matter } \\
\text { c. Students can plan the steps of completion of the given problem }\end{array}$ \\
\hline 3. & $\begin{array}{l}\text { Solve the problem according to plan } \\
\text { (carrying out theplan) }\end{array}$ & $\begin{array}{l}\text { a. Students can solve problems that exist in accordance with the steps that have } \\
\text { been made since the early } \\
\text { b. Students can answer the questions correctly. }\end{array}$ \\
\hline 4. & Check back (looking back) & $\begin{array}{l}\text { a. Students can check the answers that have been obtained by using means or } \\
\text { step in the right } \\
\text { b. Students can ascertain the accuracy of the answers that have been made. }\end{array}$ \\
\hline
\end{tabular}

Brigg Isabel Myers and Katharine C. Briggs personality to develop a model that is based on Carl Jung's theory that the MBTI (Myers-Briggs Type Indicator). Myers concludes there are 4 main ways that distinguish one person to another. Myers calls this distinction "choice" describes the parable of the "preferred hand" to show that even though we all use two hands we are, most of us choose one of the other, and that hand plays an important role in many activities that are using hands. Model Myers and Briggs, known as model "big four" which includes four dimensions. Exstraversion versus introversion, sensing Versus Intuition, Thinking Versus Feeling, Judging Perceptive Versus. ISTJ, ISTP, ESTP, ESTJ, ISFJ, ISFP, ESFP, ESFJ, INFJ, INFP, ENFP, ENFJ, INTJ, INTP, ENTP and ENTJ.

Mc Caulley and Myers Brigss explain of each personality type. ISTJ (Introverted, Sensing, Thinking, Judging) is a serious man, a quiet man, underwent successful with concentration, their practical person, very organized, factual, logical, realistic, and dependent. ISTP (Introverted, Sensing, Thinking, Perceiving) is a person who is full of enthusiasm and loyal, but rarely straight forward until everything became clear, always learning, happy ideas, language, personal projects that are free, very friendly, and a little concerned with the surroundings. ESTP (Extrovert, Sensing, Thinking, Perceiving) is a good person to solve problems, not seized with anxiety, happy with what they are, enthusiastic, happy with things related to the engine and sport, adaptable, tolerant, generally tend to be conservative the value of life, is not happy with the information that is too long. ESTJ (Extrovert, Sensing, Thinking, Judging) is the practical, realistic, based on the facts, have a mechanical aptitude and business, to accomplish something they were able to organize the work, happy and active organization. ISFJ (Introverted, Sensing, Feeling, Judging) is a quiet man, friendly, responsible, careful, working hard to fulfill their obligations.

ISFP (Introverted, Sensing, Feeling, Perceiving) is the shy, somewhat easy to make friends, sensitive, kind, humble to their ability, to avoid rejection, not impose their opinions to others. ESFP (Extrovert, Sensing, Feeling, Perceiving) are people who love out of the house, wherever he liked, friendly, easy to accept, happy things and make funny things for other people, they know what is going on and easy to take parts, like sports, it's easy to remember facts and theories. ESFJ (Extrovert, Sensing, Feeling, Judging) is a warm person, popular, talk a lot, have the spirit of gathering / organizing, conscientious, active in the organization, is very good at creating situations in harmony, always doing good for others, work well if always commended, INFJ (Introverted, Intuition, Feeling, Judging) is a successful person because of perseverance, skill and a great desire to do what is needed or desired. INFP (Introverted, Intuition, Feeling, Perceiving) is reserved and cautious, delighted with sciences theoretical, happy to resolve difficulties with logic and analysis, interested in ideas, have fun at work where interest can be used in full.

ENFP (Extrovert, Intuition, Feeling, Perceiving) is a reliable person, have enthusiasm, high-spirited, honest, imaginative, they can do all the things that interest them, quickly make decisions in difficult situations and ready to help anyone who is having trouble , ENFJ (Extrovert, Intuition, Feeling, Judging) is a very responsible, generally can feel what other people think and want, do the things that end eared others, easily become the leader of the discussion, social, popular, sympathetic, receiving praise and critics. INTJ (Introverted, Intuition, Thinking, Judging) is a person who has a genuine thoughts and great strength to the thoughts and their personal plans. INTP (Introvert, Intuition, Thinking, Perceiving) is a quiet and reserved demeanor of people very carefully even though they had no difficulty in talking a lot of things. ENTP (Extrovert, Intuition, Thinking, Perceiving) are honest, fast-acting, better in many respects, very supportive togetherness, alert and frank. ENTJ (Extrovert, Intuition, Thinking, Judging) is the hard-hearted, frankly, the leader in activity, characterized by cold, reserved, cautious, observer, 
analyzing life with an attitude of curiosity, interested in the logic of cause and effect.

The big difference in the nature and behavior of each individual affects their output when solving a problem because students differ from one another in receiving information, process information, and how to follow up the matter. Because of differences in personality of a person, they can not solve the problem with the approach and decision-making in the same way students and teachers occurs due to the influence of the different personalities (Razak et al., 2018),

\section{METHOD}

The approach used in this study is a qualitative approach to explore and understand the meaning by individuals or group of people ascribed social or humanitarian problems (Creswell, 1998). This type of research is descriptive for this study describe the profile of students' abilities to solve trigonometry problems in terms of Myer-Briggs personality type. The subject of this study is 9 students from the class of the 36 students of class X. This research was conducted at SMK Negeri 2 Boyolangu Kec.Boyolangu, Kab.Tulungagung East Java, Indonesia. The study began by giving the MBTI questionnaire. From the questionnaire found 10 of 16 myer-briggs personality type. Once grouped then researchers take the subject based on the results of mathematical problem solving ability to analyze, making the subject based on the results of tests such as the fact that there is in the field by taking the highest value of each personality type. analysis of student difficulties in solving mathematical problems need to be given an alternative solution to overcome learning difficulties so that student achievement can be increased (Trizulfianto, Anggreini D and Waluyo A).

\section{RESULTS AND DISCUSSION}

\section{Mathematical problem solving ability of students obtained ENTJ personality type.}

At this stage of understanding the problems students ENTJ personality type has been able to pass through properly by writing and mention what is known and questioned asked. In the planning stages of completion ENTJ subject to detailed planning by drawing and is capable of communicating his plans. At the stage finish ENTJ subject matter to pass through the finish at the right end result. While on stage look back and conclude the final results are not able to pass through the subject ENTJ because the subject can not conclude what she had done. The characteristics of this subject is like to analyze by reading about many times to be analyzed in order to understand the purpose of the question. Here is a table of data triangulation students' problem-solving abilities.

Table 2. Triangulation Data Phase Problem Solving Ability Students In Problem Solving Trig ENTJ Personality Type Initials FW.

\begin{tabular}{lll}
$\begin{array}{l}\text { Indicators Troubleshooting } \\
\text { Capabilities }\end{array}$ & Problem-solving skills written test stage & $\begin{array}{l}\text { Problem-solving abilities interview } \\
\text { stage }\end{array}$ \\
\hline $\begin{array}{l}\text { Stage understand the problem } \\
\text { Stage plan }\end{array}$ & $\begin{array}{l}\text { Subjects were able to write about what is known and } \\
\text { asked the questions correctly } \\
\text { Subjects were able to plan the issue before solve the } \\
\text { problem by drawing wake previously understood and } \\
\text { enter numbers that are known to picture clearly. }\end{array}$ & $\begin{array}{l}\text { Subjects were able to mention what is } \\
\text { known and asked the questions correctly } \\
\text { rencakan on the matter clearly. }\end{array}$ \\
$\begin{array}{ll}\text { Subjects were able to solve problems that have been } \\
\text { given properly. }\end{array}$ & $\begin{array}{l}\text { Subject capable of resolving the question, } \\
\text { but his finish a little trouble because of } \\
\text { the difficulties in the formula }\end{array}$ \\
Phase looking back & $\begin{array}{l}\text { The subject is not able to look back an answer } \\
\text { because it does not draw a conclusion from the } \\
\text { problem-solving. }\end{array}$ & conclusion of the matter. \\
\hline
\end{tabular}

Based on indicators of students' mathematical problem solving ability in solving mathematical problems in the theory of Polya namely: ENTJ students can understand the problems, plan solutions, complete solution. But to look back at the end of the settlement concludes the subject ENTJ can not conclude.

\section{Mathematical problem solving ability of students gained personality type ESFJ}

In the first stage of understanding the subject matter ESTJ able to understand it, although not perfect because the subject ESFJ write less complete but subject ESFJ able to mention in detail in the interview. At a later stage settlement plan subject ESFJ able to plan prior to solve the problem by drawing he knows and can explain the plan he had made the interview session. At the stage of completion of the subject matter is able to pass through these stages but imperfect and subject ESFJ bit of trouble and doubt about the answer. At the stage of looking back to conclude the final settlement ESFJ subject able to pass through this stage to conclude the work on the subject ESFJ interview session but did not write the conclusion on the answer sheet on the grounds do not know if given conclusion because it is not 
instructed to make a conclusion. The characteristics of the personality type that is not thinking long ESTJ answered as best he could with the existing problems without thinking about whether the answer was correct or not.

Problem solving is a process that is still difficult for the subject of one of them on stage to solve the problem, so not all the questions were done properly. Based on indicators of students' mathematical problem solving in solving mathematical problems in which the subject ESFJ Polya theory can not pass all the indicators well, from understanding the problems, plan solutions, complete solutions, and check back answers. So it can not produce a systematic problem-solving, but the subject is able to explain when the interview.

\section{Mathematical problem solving ability of students gained personality type ESTP}

The first phase of the subject's personality type ESTP able to pass well to write and mention is complete and correct. On completion of the planning stage ESTP subjects were able to pass perfectly to plan in advance before completion in width answer and be able to tell the plans made. On step settlement subject matter ESTP able to pass through but the solution is still less than perfect. And step look back at the end of the settlement concludes the subject ESTP able to pass through to the completion of the conclusion of the session mentioning the interview but did not write the answer on the grounds on sheet conclusions are not accustomed to write the conclusion. Traits that appear in the subject ESTP personality type that is enthusiastic, it is proved by the subject matter of a given spirit working on problemsolving ability, means the characteristic enthusiasm owned subject is able to affect the ability of problem solving.

Based on the ability of the subject mathematical problem solving by Polya theory that understanding the problems, plan solutions, complete solutions, and look back to conclude the final settlement. Subject ESTP still difficulties in stage solve the problem because the answer is still wrong. So it can not produce a systematic problem-solving. But the subject ESTP able to explain in an interview.

\section{Mathematical problem solving ability of students obtained INFJ personality type}

Subjects who have INFJ personality on stage to understand the problem has been able to achieve but there is little shortage in one write about because less complete but at the time of the interview subjects INFJ able to mention it. On completion of the planning stage INFJ subject can pass through, but planning is still less than perfect due to lack of detailed planning. At the stage of completion of the subject matter INFJ able to pass through these stages but not maximized because the result is still wrong. At the stage of looking back to conclude the final settlement with the subject is able to pass through the settlement concluded in the interview but on the answer sheet about writing the subject for some reason forgotten.

Problem solving is a process that is still difficult for the subject of one of them on the stage of completion of the subject matter so that the answer is still wrong. Based on indicators of students' mathematical problem solving ability in solving mathematical problems by Polya theory, the subject has not been able to get past INFJ good indicator of understanding the problems, plan solutions, complete solutions, and look back and conclude the final results. So it can not generate a systematic problem solving, but the subject INFJ is able to explain the interview session.

\section{Mathematical problem solving ability of students obtained INTP personality type}

Step problem-solving ability to understand the subject matter of INTP able to pass through by saying things that were asked and known about in the interview but the subject a little trouble understanding the subject matter and do not write with complete INTP on sheet answers. In the planning stages of completion subject INTP able to pass through the plan before finalizing the settlement but planning is incomplete and the subject is able to tell what he had planned. At the stage of completion of the subject finish able to pass through these stages have been trying to solve the subject INTP but the answer is still wrong and difficulties when describing the interview session. At the stage of looking back to conclude the final settlement INTP subject was unable to pass through this stage because the subject can not be summed INTP well in the written test and interview. The characteristics that appear in the subject INTP personality type that is likely to follow their own thoughts because this subject considers the settlement should not conclude more results.

Problem solving is a process that is still difficult for this subject one stage looked back to conclude the final settlement, so that all subject matter is not concluded by the INTP. Based on indicators of students' mathematical problem solving in solving mathematical problems by Polya Theory INTP subject has not been able to go through all of the indicators with both understand, plan, resolve, and especially on looking back. So it is can not produce systematic problem-solving. But the subject was able to explain in an interview.

\section{Mathematical problem solving ability of students gained personality type ISFJ}

At this stage of understanding the subject matter of personality types ISFJ able to pass through these stages to mention anything about the note and asked at the interview but the writing test subjects ISFJ write it less than perfect. In the planning stage of the subject matter ISFJ able to pass through this stage with what was 
planned tell before but planning is imperfect too. On the stage of completing a subject matter ISFJ able to pass through even though the answer is still wrong but the subjects have motivation to get it done. At the stage of looking back with the final settlement concludes the subject was unable to pass through this stage because the subject is not able to make the conclusion of the settlement in the written test and interview.

Based on the indicators of problem-solving ability is a process that is still difficult for the subject ISFJ one stage looking back the subject can not make conclusions from the settlement altogether. Of indicators mathematical problem solving ability of students in solving mathematical problems in the theory of the subject Polya ISFJ not been able to pass all the indicators well. Of understanding, planning, especially at the stage finish and look back. So it can not produce systematic problem-solving, but the subject is able to explain the interview session.

\section{Mathematical problem solving ability of students obtained ISTJ personality type}

Subject ISTJ able to pass the indicators to understand and plan for the problem very well. At the stage of completion of the subject finish ISTJ able to pass through properly and are still having a bit of trouble doing it. At the stage of looking back to conclude the final settlement with the subject concluded ISTJ able to pass through during the interview session but in the written test subject does not write the conclusion for reasons not know if given conclusion. traits that appear on the subject ISTJ personality type that is always planned in advance to accomplish everything that will be done.

Based on the indicators of the ability of solving mathematical students in solving mathematical problems in the theory of Polya subject ISTJ can understand, plan, resolve, and looking back the answer, but at this stage of completing the subject matter is still a bit of trouble and stage look back on the subject can not write a conclusion on the answer sheet because do not know if in love conclusions.

\section{Mathematical problem solving ability of students obtained ISTP personality type}

Subject ISTP at the stage of understanding the problems able to pass through by saying things that are known and clearly asked the interview session but at the time of written test subject is less complete write. In the planning stages of completion subject ISTP able to pass through properly and clearly. At the stage of completion of the subject finish able to pass through but the end result is still one subject megalami little trouble but the subject ISTP have the motivation to do it. At the stage of looking back to conclude the final settlement ISTP subject able to pass through to mention the conclusion of the settlement, but the writing test subject does not write the conclusion on the answer sheet for some reason forgot to write it down. The characteristics that appear in the subject ISTP personality type of enthusiasm in answering questions.

Based on indicators of students' mathematical problem solving ability in solving mathematical problems in the theory of the subject Polya ISTP able to pass all the indicators to understand, plan, finish and look back. However, at this stage of understanding, resolve, and looking back, it is still difficult for the subject ISTP because it is not done perfectly. So it can not produce a systematic problem-solving, but the subject is able to explain in an interview.

\section{Mathematical problem solving ability of students gained personality type ESTJ}

Subject ESTJ at the stage of understanding the problems able to pass through by writing and mention the known and questioned. At the planning stage ESTJ subject matter well and clearly planned. While at the stage of completing a subject matter ESTJ able to pass through but having a little trouble completing. At the stage of looking back to conclude the final settlement estj subject able to pass through to conclude the final settlement in the interview but the writing test subject on the sheet ESTJ not write answers for some reason forgotten. Traits that appear in the subject ESTJ personality type that is to accomplish something they were able to organize the work,

Based on indicators of students' mathematical problem solving in solving mathematical problems according to Polya theory estj subject can understand, plan, complete solutions, and look back. But in understanding the subject matter and complete settlement rudimentary ESTJ do. And in view of the subject about writing back but can mention the conclusions in the interview.

\section{CONCLUSION}

Based on analysis of problem-solving abilities of vocational students in terms of personality types MyerBriggs Type Indicator (MBTI) of 9 personality types can be seen that the type of personality that has the ability to problem-solving mathematically the best that personality type ISTJ, because the subject of this type is capable of passing all solving a given indicator, it can be said that the problem-solving ability scores metematis subject ISTJ type has a level of problem-solving ability is higher than any other subject.

ENTJ personality type has a math problem solving skills are good enough so that it can meet three of the indicators Polya theory is to understand, plan, and complete. ESFJ personality type has a math problem solving skills are good with 4 indicators able to meet Polya theory. Estp personality type has a math problem solving skills are good with 4 indicators able to meet Polya theory. INFJ personality type has a math problem 
solving ability was good with 4 indicators are able to pass Polya theory. INTP personality type has a math problem solving skills are good enough to be able to meet three of the four indicators Polya existing theory. ISFJ personality type has a math problem solving skills are good enough to be able to meet three of the four indicators that exist. ISTJ personality type has a math problem-solving ability is excellent from other types with 4 indicators are able to meet very well. ISTP and ESTJ personality type has a math problem solving ability was good to meet the 4 indicators Polya theory.

\section{REFERENCES}

Agustina, R. (2014). Penyelesaian masalah matematika pada tipe kepribadian Phlegmatis. Jurnal Pendidikan Matematika FKIP Univ. Muhammadiyah Metro, 3(2), 16-22.

Aziz, A., Kusmayadi, T. A., \& Sujadi, I. (2014). Proses Berpikir Kreatif Dalam Pemecahan Masalah Matematika Ditinjau Dari Tipe Kepribadian Dimensi Myer-Briggs Siswa Kelas VIII MTs NW Suralaga Lombok Timur. 2(10), 1079-1093.

Creswell, J.W. (1998). Research design: pendekatan kualitatif, kuantitatif, dan mixed. Yogjakarta: PT Pustaka Pelajar.

Diyin, M., Agustin, A., \& Sidoarjo, U. M. (2018). Proses Berfikir Matematis Siswa Dalam Memecahkan Masalah Matematika Ditinjau Dari Tipe Kepribadian Keirsey. Madrosatuna, 2(October), 29-38.

E.W. Aryanto, Suharto, T.b Setiawan, Hobri, E. O. (2018). Profil Kemampuan Siswa Dalam Memecahkan Masalah Matematika Ditinjau Dari Tipe Kepribadian Menurut David Keirsey. Kadikma, 9, 185-193.

Hasanah, N. (2009). Analisis Proses Berpikir Siswa Dalam Memecahkan Masalah Matematika Ditinjau Dari Tipe Kepribadian Extrovert-Introvert Dan Gender. 422-435.
Hasanah, U. (2017). Analisis proses Berpikir Kreatif Dalam Memecahkan Masalah Matematika Ditinjau Dari Tipe Kepribadian The keirsey Temperament Sorter (KTS) Siswa SMA.Fakultas Tarbiyah Keguruan Universitas Islam Negeri Raden Intan Lampung

Hasanah, U., Wahyu, R., \& Putra, Y. (2017). Analisis Proses Berpikir Siswa dalam Memecahkan Masalah Matematika Ditinjau Dari Tipe Kepribadian Rational dan Artisan. (d), 137-149.

Ilmiyana, M. (2018). Analisis Kemampuan Pemecahan Masalah Matematis Siswa SMA Ditinjau Dari Tipe Kepribadian Dimensi Myer Briggs Tipe Indicator (MBTI). Fakultas Tarbiyah Keguruan Universitas Islam Negeri Raden Intan Lampung $1440 \mathrm{H} / 2018 \mathrm{M}$.

Raden, I., \& Lampung, I. (2016). Proses Berpikir Matematis Siswa dalam Menyelesaikan Masalah Matematika Ditinjau dari Tipe Kepribadian Keirsey. Jurnal Pendidikan Matematika, 7(2).231-248

Razak, F., Sutrisno, A. B., Kamaruddin, R., Matematika, P. P., Lamaruddani, J., \& Pangkep, K. (2018). Deskripsi Pemecahan Masalah Matematika berdasarkan Langkah Polya ditinjau dari Kepribadian Siswa Tipe Melankolis. 4(1), 86-93.

Rohim, M. F., \& Sari, A. F. (2019). Keterampilan Siswa Memecahkan Masalah Olimpiade Matematika Ditinjau dari Kepribadian Tipe Senising dan Intuiting. 5(1), 80-92.

Trizulfianto, Anggreini D dan Adi Waluyo A. (2017). Analisis Kesulitan Siswa Dalam Memecahkan Masalah Matematika Materi Program Linier Berdasarkan Gaya Belajar Siswa. Union: Jurnal Pendidikan Matematika. 5 (2). 195-208

Yuwono, A. (2010). Profil Siswa SMA Dalam Memecahkan Masalah Matematika Ditinjau Dari Tipe Kepribadian. Program Studi Pendidikan Matematika Program Pascasarjana Universitas Sebelas Maret Surakarta 2010. 